\title{
O CASO SIMONE A. DINIZ: A FALTA DE ACESSO À JUSTIÇA PARA AS VÍTIMAS DOS CRIMES RACIAIS DA LEI CAÓ
}

\author{
Fábio Feliciano Barbosa*
}

\begin{abstract}
SUMÁRIO: 1. Introdução. 2. O Caso Simone A. Diniz: primeiras informações. 3. O nascimento interno do Caso. 4. A reação do juiz ao pedido do parque para arquivar o Caso. 5. Os efeitos do arquivamento do inquérito policial do Caso. 6.Os fundamentos da denúncia de Simone junto à CIDH. 7. A estratégia que Simone e os peticionários usaram para fazer com que a CIDH aceitasse e julgasse o Caso. 8. O tratamento jurídico que a justiça brasileira dispensou ao Caso. 9. O pedido de condenação e a defesa do Estado brasileiro. 10. A decisão de mérito da CIDH sobre o Caso. 11. O que ensinar a partir da análise do Caso sobre a falta de acesso à justiça para as vítimas dos crimes raciais da Lei Caó. 12. Conclusão. 13. Referências bibliográficas.
\end{abstract}

RESUMO: No Brasil, a prática do racismo é crime, porém as vítimas desse delito têm pouco (ou quase nenhum) acesso à justiça. Como o Brasil não tem leis abertamente (textualmente) racistas, estudaremos esse fenômeno a partir da análise de um caso concreto. Analisaremos o Caso Simone A. Diniz - a primeira condenação internacional do Brasil, junto à Comissão Interamericana dos Direitos Humanos (CIDH), por causa do racismo. Depois de avaliar a denúncia que deu origem a esse Caso, a CIDH concluiu que o Estado Brasileiro não assegura acesso à justiça às vítimas dos crimes raciais, conforme a Convenção Interamericana dos Direitos Humanos (CADH). Cremos que o estudo desse tipo de caso ajudará a elucidar porque o Brasil tem Constituições e leis contrárias ao racismo e à racialização que têm pouca aplicação e efetividade.

Palavras chaves: Acesso à Justiça. Convenção Interamericana dos Direitos Humanos. Crime de Racismo.

ABSTRACT: In Brazil, the practice of racism is a crime, but victims of this crime have little (or almost no) access to justice. As Brazil has no laws overtly (textually) racist, we study this phenomenon through the analysis of a case. If we analyze the Simone A. Diniz was the first international condemnation of Brazil, along the Inter-American Commission on Human Rights, because of racism. After evaluating the complaint that gave rise to this case, the Commission concluded that the State did not ensure access to justice to victims of racial crimes, according to the Inter-American Convention on Human Rights. We believe that this type of case study will help elucidate.

Keywords: Access to Justice. Inter-American Convention on Human Rights. Crime of racism.

\section{INTRODUÇÃO}

O presente trabalho é uma análise do conteúdo do Caso Simone A. Diniz $\left(\right.$ Caso $\left.\mathrm{SAD}^{1}\right)$. Trata-se da primeira condenação do Estado Brasileiro junto à Comissão Interamericana de Direitos Humanos (CIDH) da OEA em virtude do racismo. A Comissão ${ }^{2}$, depois de estudar esse Caso, concluiu que o Estado

\footnotetext{
* Especialista em Direito Público (UCAM) e Mestre em Políticas Públicas e Formação Humana (UERJ). Bacharel em Direito UFRJ. Advogado. Professor universitário (Escola de Direito da FGV-RJ).

1 Caso Simone André Diniz. Relatório de Mérito. OEA/CIDH. 2006. Disponível em: <SAD http://www.cidh.org/annualrep/2006port/BRASIL.12001port.htm>. Acessado em: 27 de fevereiro de 2009.

${ }^{2}$ Para saber mais sobre a composição, o funcionamento e a competências da Comissão, consultar o art. 34 e seg. da Convenção Americana sobre os Direitos Humanos. Disponível em: $<$ http://www.oas.org/juridico/portuguese/carta.htm>. Acesso em: 09 de agosto de 2009.
}

Revista de Estudos Jurídicos, a. 15, n. 22, 2011 
brasileiro não assegura acesso à justiça (e justiça) para as vítimas dos crimes raciais, o que, por contrariar o texto da Convenção Interamericana de Direitos (CADH), constitui violação dos direitos humanos.

Estudaremos o Caso SAD para: a) perquirir porque a principal lei que o Brasil criou para combater as "racializações criminosas" - a tão popular Lei Caó, criada no final dos anos 80 - não tem muita aplicação e efetividade; b) elucidar (se e) como é que os intérpretes (aplicadores) do direito da justiça contribuem para que isso aconteça; c) saber qual é a relação existente entre o tratamento jurídico-hermenêutico que esses intérpretes do direito dispensam às denúncias de racialização criminosa e a falta de acesso à justiça para as vítimas desse fenômeno, que, segundo a $\mathrm{CIDH}$, é uma injustiça que costuma ser ignorada ou tratada inadequadamente com muita facilidade, pelos intérpretes do direito que atuam na distribuição e administração da justiça no Brasil. O tipo de falta de acesso à justiça que acabamos de apontar, cujas origens estão na cor e/ou raça negra dos indivíduos, é consequiência direta e imediata da ausência de zelo do Estado brasileiro em promover a afetividade e a tutela dos direitos fundamentais de aproximadamente $45 \%$ da populacional nacional - esse é segundo o IBGE o percentual da população negra afro-descentes do Brasil.

O Caso SAD é uma importante fonte de informações (dados) sobre a qualidade do tratamento jurídico-hermenêutico que as vítimas (negras) dos crimes raciais e racismos institucionais recebem do Estado brasileiro. Não é do hoje que a literatura jurídica e sócio-jurídica sobre a qualidade desse tratamento indica que ele pode afetar (negativamente) a quantidade de casos que são analisados e decididos pela justiça brasileira. O Caso SAD, condenação histórica que o Estado brasileiro obteve junto ao Sistema Interamericano de Proteção dos Direitos Humanos (SIPDH), após o a redemocratização dos anos 80, cujo ponto culminante foi à criação da Constituição de 88 , não foge a essa regra. Lembramos que a $\mathrm{CF} / 88$ se comprometeu a dar mais efetividade aos direitos humanos, a democracia e o combate das discriminações raciais. Por conta desse compromisso. Por essas razões, fortaleceu e ampliou os recursos jurídicos que podem (e devem) ser empregados no combate ao racismo e a prática do racismo, impondo que ela seja tratada pela com crime inafiançável e imprescritível. Além disso, expressamente, fez desse citado combate um dos objetivos fundamentais da república brasileira. Devemos somar a esses recursos de combate ao racismo (institucional) as políticas públicas que, nos últimos dez anos, introduziram no Brasil as políticas de cotas e as ações afirmativas para garantir o ingresso de negros ao ensino superior.

O Caso SAD foi escolhido para ser analisado porque é um exemplo clássico de micro-história da qual podemos extrair informações, lições e diagnósticos sobre a falta de punição da racialização criminosa, e as razões do racismo institucional da justiça brasileira. Segundo Boris Fausto 
A partir de historiadores [...] como Carlo Ginzburg, Giovanni Levi [e] Le Roy Ladurie, desde [...] 1970, a micro-história tornou-se um gênero histórico muito prestigioso no mundo ocidental. Seus objetivos básicos podem ser assim resumidos: a) reduzir a escala de observação [...] a fim de apreciar ações humanas e significados que passam despercebidos quando se lida com grandes quadros; b) concentrar essa escala em pessoas comuns e não em grandes personagens [...] c) extrair de fatos aparentemente corriqueiros uma dimensão sócio-cultural relevante (FAUSTO, 2009, p. 9)

Acreditamos que o uso da micro-histórica revelará aspectos culturais, históricos, ideológicos, psicológicos e sócio-jurídicos relevantes sobre as hermenêuticas e as aplicações que os intérpretes do direito da justiça brasileira dão os recursos jurídicos que combatem os efeitos da discriminação racial. Além disso, o estudo do Caso elucidou e diagnosticou a relação que há entre essas interpretações, as aplicações (usos práticos) do direito e o pouco acesso à justiça para os negros racializados.

Ressaltamos que, desde a criação da Carta Constitucional de 1934, o direito positivo brasileiro vem, progressivamente, proibindo as discriminações com base na raça e/ou cor; e que, desde a década de 50, criminaliza algumas delas - como proibir a entrada de pessoas da raça (cor) negra em estabelecimentos comerciais e escolas, públicas ou privadas. Desde a metade do século XX, o Estado do Brasil conta com leis que criminalizam a prática do racismo por meio das quais foram tipificadas as condutas racializadoras criminosas, ou racializações criminosas. A Consolidação das Leis do Trabalho (CLT), Decreto-Lei 5.453, de 01.05.43, em seu art. 461, institui a proibição de qualquer tipo de discriminação que tenha fundamento na raça (e/ou cor) dos trabalhadores.

No ano de 1951, o Brasil criou a primeira lei que tipificou as racializações criminosas do direito brasileiro, a Lei Afonso Arinos. E, no final dos anos 80, a $\mathrm{CF} / 88$, em seu art. $5^{\circ}$, XLII, determinou que "a prática do racismo é um crime inafiançável, imprescritível, sujeito à pena de reclusão nos termos da lei”. ${ }^{3}$

Por conta dessa determinação constitucional mais gravosa, em 1989, o Congresso Nacional criou a Lei Caó - o mais popular dos recursos jurídicos do direito brasileiro que podem ser empregados no combate a prática do racismo. Mesmo dispondo desse e outros recursos legais, a Comissão externou que no Brasil é muito raro haver acesso à justiça, justiça e garantia igual de direito para as negras e os negros racializados que denunciam e buscam tribunalizar as racializações criminosas que sofrem por causa da cor e/ou raça.

Acreditamos que o estudo de caso é uma boa estratégia de investigação sócio-jurídica sobre a histórica falta de acesso à justiça para as negras e os negros racializados, uma vez que a literatura nacional e estrangeira sobre o acesso à

\footnotetext{
${ }^{3}$ Além dessas duas leis históricas, no final dos anos 90, o Estado brasileiro criou a lei de n. 9.455, de 07.04. 97, que criminalizou a prática da tortura. No seu artigo 1, I, C, essa lei determina que é crime de tortura "constranger alguém, mediante o emprego de violência ou grave ameaça, causando-lhe sofrimento físico ou mental em razão de discriminação racial ou religiosa (pena - reclusão de 2 (dois) a 8 (oito) anos. <http://www.planalto.gov.br/ccivil/LEIS/L9455.htm>.
} 
justiça, consagrada pelos trabalhos de Mauro Cappelletti e Bryant Garth (1988), limita-se a constatar que ela existe, sem buscar as suas razões mais profundas. Essa estratégia pode contribuir para desfazer um poderoso mito: a intérpretes do direito da justiça brasileira não são sensíveis ao que os estudiosos do racismo e legislação que prima para garantia da igualdade - como Antonio Sergio Guimarães (2004), Evandro Charles Piza Duarte (2006), Sérgio Abreu (1999) Kátia Elenise Oliveira da Silva (2001) e Jorge da Silva (1994) - chamam de discriminação motivada por preconceito de cor e/ou de raça. Adiantamos que estudar e desfazer esse mito - muito poderoso e popular na sociedade brasileira poderá significar mais acesso à justiça, justiça e garantia de direitos para as negras e os negros do Brasil.

O Caso SAD é paradigmático porque conta a história de uma mulher negra que, como vamos veremos, foi racializada quando procurava uma oportunidade de trabalho. Além disso, nele há pistas muito consistentes sobre os racismos institucionais que as negras e os negros racializados precisam enfrentar e vencer por causa das hermenêuticas que os intérpretes do direito criam e usam para justificar (ou não) a aplicação dos recursos jurídicos que combatem o racismo, aqui representados pela já citada Lei Caó.

\section{O CASO SIMONE A. DINIZ: PRIMEIRAS INFORMAÇÕES}

No ano de 2006, a CIDH "condenou" o Estado do brasileiro porque, depois de analisar a denúncia que deu origem ao Caso $\mathrm{SAD}$, considerou que ele não assegura às vítimas do racismo institucional e crimes raciais acesso à justiça, tratamento igual e justiça, garantias previstas no texto da CADH. Essa condenação teve origem numa petição encaminhada à $\mathrm{CIDH}$, formulada por Simone A. Diniz (a vítima) e os demais peticionários do Caso, como o CEJIL e Geledés, ONGs que, na época, militavam (e ainda hoje militam) em prol dos direitos humanos. ${ }^{4}$

Cecília MacDowell Santos lembra que, antes da decisão sobre o Caso $\mathrm{SAD}$, a CIDH só havia chamado a atenção

do Estado Brasileiro apenas duas vezes, em 1972 e 1985. Durante a ditadura, [a $\mathrm{CIDH}]$ ignorou a grande maioria das denúncias apresentadas contra o Brasil. De 1969 a 1973, por exemplo [...] recebeu, pelo menos, 77 petições contra o Brasil [e somente] 20 foram aceitas como "casos concretos". Todas, com exceção de uma, estão relacionadas com a prática de detenção arbitrária, ameaça de morte, tortura, desaparecimento, assassinato perpetuado por agentes estatais contra dissidentes políticos do regime [militar de 1964] (Santos, 2007, p. 27).

Paulo de Tarso Lugon Arantes atesta que o Caso SAD foi

\footnotetext{
${ }^{4}$ O Centro Internacional pela Justiça e o Direito Internacional e o Instituto da Mulher Negra assinaram, junto com Simone, a petição que deu origem ao Caso.
} 
O primeiro caso contencioso internacional contra o Brasil, que analisa, à luz do Direito Internacional dos Direitos Humanos, a discriminação racial [...] O caso também é relevante por sua abrangência social, porquanto projeta a discriminação individual sofrida pela vítima [Simone] a um padrão de discriminação racial, com especial atenção aos obstáculos legislativos e jurisprudenciais nacionais que impedem as vítimas de sanarem as violações sofridas. (ARANTES, 2007, p.128).

\section{O Caso é um exemplo clássico de racismo institucional, sobre o qual Ellis Cashmore diz que}

embora [...] possa ser definido, num certo sentido, como uma crença ou idéias de indivíduos, em seu sentido institucional ele diz respeito às operações anônimas de discriminação em organizações, profissões, ou até mesmo sociedades inteiras. É anônimo à medida em que os indivíduos podem negar a acusação de racismo e se livrarem das responsabilidades. Mais que isso, se o padrão da exclusão persiste, as causas devem ser procuradas nas instituições às quais ele está ligado, nas suposições não expressas nas quais tais organizações fundamentam as suas práticas e nos inquestionáveis princípios que, eventualmente, possam usar [esse conceito] foi introduzido pela primeira vez pelos ativistas negros Stokely Carmichael e Charles V. Hamilton [...] o racismo institucional é camuflado uma vez que suas causas específicas não são detectáveis, embora seus efeitos e resultados sejam bastante visíveis [ele] é mascarado nos procedimentos das indústrias, das escolas, partidos políticos, etc [...] A força do racismo institucional está em capturar as maneiras pelas quais sociedades inteiras, ou seções delas, são afetadas pelo racismo, ou talvez por legados racistas, muito tempo depois dos indivíduos racistas terem desaparecido [à força do racismo institucional], contudo, é, sob um ponto de vista diferente, também sua fraqueza: uma acusação de racismo institucional permite que todos saiam ilesos; somente a instituição abstrata é passível de culpa. Os críticos insistem que as instituições são, no fim das contas, o resultado de tentativas humanas, e que é absolutamente um erro supor que o racismo institucional seria um causa. (CASHMORE, 1989, pp. 169, 170)

\section{Michel Wieviorka ao falar sobre esse mesmo conceito assevera que}

a força [do] racismo institucional é indicar que o declínio das doutrinas científicas de raça não implica de modo algum a do próprio racismo: constata-se facilmente que lá onde racismo está desqualificado politicamente, interdito por lei, arruinado aos olhos dos cientistas, lá onde os preconceitos não têm quase espaço para se exprimir, se nada é empreendido de maneira voluntariosa para contrariar as tendências espontâneas das instituições os membros dos grupos vítimas do racismo permanecem confinados em postos subalternos da vida econômica e política, ou sofrem a discriminação no emprego, na habitação e na educação [...] 
segundo essa teoria, somente as instituições, no fim das contas, funcionam no racismo e, ao mesmo tempo, ele faz recair sobre todos a responsabilidade do fenômeno. A utilidade do conceito de racismo institucional é talvez, antes de tudo, a de pleitear que se ouçam aqueles que sofrem a discriminação e a segregação e que pedem as mudanças políticas e institucionais para retificar as desigualdades e as injustiças de que são vítimas [...] A tese do racismo institucional sugere que as formas contemporâneas do fenômeno podem, ao mesmo parcialmente, se desdobrar a partir de baixo, atravessando as estruturas sociais, sem ter a necessidade de uma forte estruturação ideológica ou doutrinária; mas ela dá a entender que o racismo depende de mecanismos que funcionam sem atores sociais [...] No fundo, a noção de racismo institucional apresenta a utilidade de acentuar as formas não flagrantes ou não brutais do racismo, suas expressões veladas, pois transitam nas instituições; mas ela se torna insuficiente a partir do momento em que faz do racismo um fenômeno abstrato, a repousar aparentemente sobre mecanismos abstratos, sem atores (WIEVIORKA, 2007, pp. 32, 33)

Após uma rápida exposição sobre a importância histórica e jurídicosociológica do Caso e o que é o racismo institucional, abordaremos as razões do seu nascimento, o tratamento jurídico-hermenêutico que ele recebeu dos intérpretes do direito da justiça brasileira e por qual razão ele foi apresentado à Comissão, tornando-se um caso internacional de violação dos direitos humanos.

\section{O NASCIMENTO INTERNO DO CASO}

Em 05.03.97, Simone A. Diniz relatou à autoridade policial que fora vítima de um crime racial. Contou e denunciou à autoridade policial que Aparecida Gisele Mota da Silva publicou, na Folha de São Paulo, em 02.03.97, um anúncio nos classificados no qual ofertava uma vaga de empregada doméstica para a qual só seriam aceitas e contratadas as candidatas que fossem "preferencialmente brancas". Segundo depoimentos colhidos pela autoridade policial, no curso da investigação dos fatos, ao ligar para o número que constava no citado anúncio, Simone foi atendida por "alguém" que, rapitadamente, perguntou: "Você é branca ou negra?". Simone respondeu: "Sou negra". De imediato ouviu que, por essa razão, não seria aceita para o emprego, já que o seu perfil - não ser da cor/raça branca - não combinava com a vaga oferecida.

$\mathrm{Na}$ verdade, Simone acusou Aparecida Gisele de ter violado o artigo 20 da Lei Caó, de n. 7.716/89, alterada pela Lei 8081/90, em cujo texto consta que é crime "praticar, induzir ou incitar, pelos meios de comunicação social ou por publicação de qualquer natureza, a discriminação ou preconceito por raça, religião, etnia ou origem. Pena: reclusão de dois e cinco anos".

Wilson Lavorenti lembra que os crimes desse diploma legal estão sujeitos às penas de reclusão, e que 
Todos [eles] têm como objeto jurídico tutelar o tratamento igualitário. Como regra, são crimes comuns, podendo ter como sujeito ativo ou passivo qualquer pessoa. Todos exigem o dolo [do agente racializador] como elemento subjetivo do tipo [e demandam a proposição de uma] ação penal pública incondicionada (LAVORENTI, 2006, p. 292).

A Lei Caó, no texto do art. 20, instituiu que pratica um crime racial, de natureza inafiançável e imprescritível, o agente que divulga idéias racistas, estabelece e/ou realiza tratamentos que violam a garantia constitucional do tratamento igualitário entre os negros e brancos, por exemplo. Os crimes dessa lei são delitos graves que atentam contra a garantia constitucional da igualdade, um das vigas mestra do Estado democrático de direito. Por essa razão, eles estão sujeitos a proposição de uma ação penal pública incondicionada, o que, segundo a $\mathrm{CF} / 88$, só pode ser apresentada à justiça pelo ministério público, depois de instaurado e concluído o inquérito policial.

A fim de apurar a denúncia de Simone e colher elementos que esclarecessem mais os fatos, a autoridade policial instaurou o inquérito policial, no dia 05.03.1997. A partir dessa data, começou a colher o depoimento dos seguintes envolvidos: a) Simone, a vítima; b) Aparecida Gisele; a acusada de ser a gente racializadora; c) Jorge Honório da Silva; o marido e testemunha da acusada; d) os relatos de uma amiga da vítima que, inquirida em sede policial, confirmou o teor da ligação com a qual Simone foi informada que, por ser negra, não seria contratada.

A acusada e o seu marido confirmaram à autoridade policial o conteúdo do anúncio do jornal, e da ligação citada nas últimas linhas do parágrafo anterior. Os depoentes disseram, sem meias palavras, que só contratariam mulheres brancas porque as negras batem nas crianças confiadas a sua guarda. Justificaram essa preferência porque os seus filhos ficaram traumatizados com as agressões praticadas por uma ex-empregada negra.

Terminado o inquérito policial, conforme determina a Código de Processo Penal, o delegado remeteu os autos ao promotor de justiça. Depois de analisálos, em 02.04.1997, ele requisitou ao juiz que os arquivasse por não haver provas que atestassem o dolo da acusada - a sua verdadeira intenção de discriminar alguém por causa da cor e/ou raça. Esse dolo de discriminar é condição subjetiva do agente que, segundo a doutrina e a jurisprudência dominante, entre os intérpretes do direito da justiça brasileira, é fundamental para atestar indícios de autoria, a prática e a consumação dos crimes raciais do direito brasileiro.

$\mathrm{O}$ promotor de justiça, com certeza, influenciado pela ideologia da democracia racial, criada para eufemizar (naturalizar) os efeitos do racismo e a falta de punição dos crimes raciais, considerou que não havia provas do dolo da agente porque ela era casada com um homem negro, com o qual tinha filhos. O nascimento dessa ideologia, cujos mitos transmitem a idéia de que o Brasil é um país livre de verdadeiros racistas, racismos e conflitos raciais abertos, é tributado a publicação de 
Casa Grande \& Senzala, de Gilberto Freyre (1995) ${ }^{5}$. Além disso, para fundamentar a sua decisão, fruto da sua hermenêutica da Lei Caó e dos fatos, o parquet destacou que a acusada disse à polícia, quando estavam sendo inquirida pela autoridade, que não desejava discriminar ninguém por causa da raça.

\section{A REAÇÃO DO JUIZ AO PEDIDO DO PARQUE PARA ARQUIVAR O CASO}

Em 11 de abril de1997, o juiz decretou o arquivamento do Caso, por concordar com a tese (hermenêutica) do parquet sobre a falta de comprovação do dolo da acusada. Com base nas considerações da CIDH sobre o Caso, asseveramos que essa concordância de argumentos não é um ato isolado, mas reflexo de uma rotina institucional racializadora do poder judiciário e ministério público - órgãos essenciais para a discussão e criação das hermenêuticas e, conseguentes, aplicações do direito (dos direitos, melhor dizendo) que darão vida a distribuição e administração da justiça.

Há lastro doutrinário que explicaria e legitimaria o pedido do parquet e a decisão juiz? Sim. Para Damásio de Jesus (2001) e Bitencourt (2001), renomados penalistas brasileiros, a comprovação do dolo do agente é uma "prova" que a doutrina, a jurisprudência e a justiça cobram dos acusadores, vítimas e advogados para que uma denúncia de prática de racialização criminosa seja aceita e, assim, futuramente, dê origem a um processo judicial.

$\mathrm{Na}$ prática, à luz do direito vivo (law in action) que vige nos tribunais e instituições que servem à justiça é justo o parquet pedir o arquivamento do inquérito policial ao juiz (do Caso) quando não há provas cabais de que o dolo do agente é do tipo contumaz e contundente. Nesse caso, o magistrado deve seguir o entendimento (hermenêutica) do ministério público e deferir, sem

${ }^{5} \mathrm{O}$ marco fundador dessa ideologia, na verdade, foram os pensamentos (interpretações) de Gilberto Freyre sobre o Brasil e os brasileiros, contidos em duas obras de sua autoria: Interpretação do Brasil e Casa Grande \& Senzala. Publicadas nos anos 30/40, lançaram as bases epistemológicas para a criação de interpretações e representações sociais que eufemizam a natureza das nossas relações raciais e práticas racializadoras. Nelas, a sociedade brasileira, os conflitos de cor e/ou de raça, entre os negros e brancos, nunca têm a mesma importância e força que alcançaram nos USA e outros países - centrais ou (semi)periféricos - nos quais o racismo foi abertamente assumido, legalizado e praticado por agentes estatais e particulares. Esses estudos de Roberto Freyre produziram versões sobre o Brasil - dominadas por representações sociais - nas quais, no passado colonial, e nos tempos mais recentes, as contradições de cor e/ou de raça entre os negros e brancos sempre são apresentadas, descritas e definidas como coisas mais tênues do que as suas congêneres dos países que não foram alvo da colonização portuguesa considerada mais suave e tolerante com os colonizados e negros. Os brasileiros, na visão de Freyre e dos defensores das suas idéias, herdaram do colonizador português, supostamente mais dócil do que os espanhóis, franceses e ingleses, no trato com os escravos e colonizados, uma grande aptidão para a mistura e miscigenação. Essa herança seria responsável pela suavidade das nossas relações e conflitos raciais. Sobre as obras e as idéias de Gilberto Freyre consultar: a) ALBUQUERQUE, Roberto Cavalcanti de. Gilberto Freyre e a invenção do Brasil. Rio de Janeiro: José Olímpio, 2000; b) CHACON, Vamireh. A construção da brasilidade. Brasília: Paralelo 15 / São Paulo: Marco Zero, 2001; c) ARAÚJO, Ricardo Benzaquen de. Guerra e Paz - Casa Grande \& Senzala e a obra de Gilberto Freyre nos anos 30. São Paulo: Editora 34, 1994. 
delongas, o arquivamento do inquérito policial. Foi isso que aconteceu no Caso em questão.

\section{OS EFEITOS DO ARQUIVAMENTO DO INQUÉRITO POLICIAL DO CASO}

Primeiro, Simone ficou sem acesso à justiça, já que foi privada de obter uma decisão jurídica que objetivamente esclarecesse se houve (ou não) violação do seu direito a igualdade, e outros. Segundo, enquanto não surgissem novas provas e indícios, ela não poderia reapresentar o seu caso à justiça. Terceiro, o arquivamento nesse tipo de situação, segundo as considerações da $\mathrm{CIDH}$, equivale a uma sentença definitiva quanto ao mérito da questão. Quarto, por essa razão, esgotaram-se todas as possibilidades de Simone usar os recursos internos do direito brasileiro para conseguir da justiça brasileira uma reparação efetiva pela violação dos seus direitos. Logo, por conta do exposto, só restou a Simone uma saída para ter acesso à justiça (e justiça): denunciar o seu Caso a um órgão internacional de proteção dos direitos humanos. E foi o que aconteceu, já que o Brasil é membro da OEA, signatário da CADH e reconhece a competência da CIDH para decidir casos de violação das garantias dessa lei internacional.

\section{OS FUNDAMENTOS DA DENÚNCIA DE SIMONE JUNTO À CIDH}

Simone denunciou o seu caso à CIDH porque, segundo ela e os demais peticionários, a justiça brasileira negou-lhe acesso à justiça (e justiça) por causa da sua raça e/ou cor. Alegaram que esse tipo de negação é uma rotina racializadora institucionalizada no cotidiano da justiça brasileira, o que viola as garantias da CADH.

Os peticionários também lembraram a CIDH que o Estado brasileiro, enquanto signatário da $\mathrm{CADH}$, que no art. 3 trata da Obrigação de não Discriminar, se comprometeu a garantir os direitos dessa Convenção aos seus jurisdicionados "sem discriminação alguma por motivo de raça, cor, sexo, idioma, religião, opiniões políticas ou de qualquer outra natureza, origem nacional ou social, posição econômica, nascimento ou qualquer outra condição social". Destacaram outrossim que, dentre as garantias positivadas pela CADH estão à igualdade perante a lei (art. 24) e a igual proteção judicial (art. 25), além da garantia de acesso efetivo à justiça.

Os trabalhos de Antonio Cançado Trindade (1997; 1998) e Flávia Piovesan $(2007 ; 2008)$ sobre o sistema interamericano de proteção dos direitos humanos indicam que, para as violações desses direitos serem avaliadas pela $\mathrm{CIDH}$, é preciso à comprovação de que a vítima esgotou, sem sucesso, todos os recursos jurídicos internos a fim de obter acesso à justiça. Além dessa comprovação, ela deve indicar a garantia (norma) da CADH que foi violada, quando isso aconteceu e que é o provável autor - um Estado soberano da OEA, por exemplo. 
Depois de comprovada às formalidades retro apontadas, dentro do prazo de seis meses (art. 34) "qualquer pessoa ou grupo de pessoas, ou entidade nãogovernamental legalmente reconhecida em um ou mais Estados membros da Organização, pode apresentar à $\mathrm{CIDH}$ petições que contenham denúncias de violação" das garantias da CADH.

No Caso em tela, o esgotamento dos recursos internos foi célere e de fácil comprovação, já que o arquivamento do inquérito policial, como nós apontamos em linhas anteriores, fechou de uma vez por todas às portas da justiça à Simone.

\section{A ESTRATÉGIA QUE SIMONE E OS PETICIONÁRIOS USARAM PARA FAZER COM QUE A CIDH ACEITASSE E JULGASSE O CASO}

Os peticionários praticaram o que os estudiosos chamam de litigância transnacional, ou ativismo jurídico transnacional. Cecília MacDowell Santos ensina que esse recurso é adequado

às disputas entre os Estados, entre indivíduos e Estados e entre
indivíduos através de suas fronteiras nacionais [e que ele não pode
ser visto] Como uma tentativa tão simplesmente de remediar
abusos individuais, mas também de (re)politizar ou (re)legalizar a
política de direitos humanos ao provocar as cortes internacionais
ou sistemas quase judiciais de direitos humanos a levá-los a
agirem diante das arenas jurídicas e políticas nacionais e locais
[...] Uma vez que o Estado é um ator principal nas batalhas
jurídicas transnacionais sobre direitos humanos, é importante
investigar tanto sobre as práticas dos defensores jurídicos
transnacionais quanto como o Estado responde a eles. Isso nos
auxilia a entender melhor não somente como os atores da
sociedade civil se engajam na mobilização jurídica transnacional,
mas também como o Estado se refere às normas internacionais de
direitos humanos e como os discursos e as práticas ligados aos
direitos humanos são desenvolvidos em diferentes setores do
Estado e em diversos níveis da atuação estatal. (SANTOS, 2007,
p. 27, 28)

Sem o emprego desse recurso estratégico, muitos casos de violações dos dispositivos da $\mathrm{CADH}$ ficariam impunes porque têm origem em ações ou omissões de Estados que, mesmo sendo signatários da $\mathrm{CADH}$, não as apuram adequadamente no plano interno. $\mathrm{O}$ ativismo jurídico internacional tem sido usado por inúmeras ONGs pró-direitos humanos para dar visibilidade e solução às violações desses direitos nos países da América Latina, praticadas após a criação das Constituições que, nas décadas 80 e 90, deram fim as ditaduras militares, surgidas nos anos 60 e 70 . Nessas novas Cartas, a promessa de garantia e promoção dos direitos humanos das mulheres, negros e índios, como é o caso do Brasil, Argentina e Chile, por exemplo, passou a ser um elemento legitimador de novas democracias, nas quais o acesso à justiça é crucial para a garantia dos direitos. Porém, conforme indicam as considerações da CIDH, a 
aplicação e a efetividade das garantias jurídicas (fundamentais e universais) que constituem os direitos humanos ainda são muito precárias nas jovens democracias da América Latina.

\section{O TRATAMENTO JURÍDICO QUE A JUSTIÇA BRASILEIRA DISPENSOU AO CASO}

Nessa parte do texto, analisaremos as hermenêuticas legais, as rotinas institucionais e as decisões produzidas pelos intérpretes do direito ${ }^{6}$ que apuraram os fatos e, por esse motivo, emitiram um juízo de valor sobre a denúncia de Simone, e o teor (significado) do art. 20 da Lei Caó. A partir dessa análise esboçamos as linhas gerais do tratamento jurídico-hermenêutico que os intérpretes do direito da justiça brasileira dispensam as denúncias de prática de racialização criminosa, prevista na Lei Caó. Essa análise permitiu a identificação de algumas singularidades do racismo institucional da justiça brasileira, e o entendimento sobre o que os seus intérpretes julgam ser a prática de uma verdadeira racialização criminosa.

De início, temos a hermenêutica da autoridade policial que, depois de colher e analisar os depoimentos dos envolvidos, resolveu indiciar a acusada Gisele Aparecida por violação do art. 20 da Lei Caó. Em seguida, analisaremos o entendimento do parquet que, como apontamos, pediu o arquivamento do caso ao juiz depois que leu e interpretou o que o delgado disso sobre o Caso. Por fim, a análise da hermenêutica do juiz do Caso que, por concordar com os argumentos do parquet sobre o Caso e a falta de comprovação do dolo da agente racializadora, fez o que lhe foi solicitado: decretou o arquivamento do inquérito policial.

Começaremos pela leitura e, posterior, análise do conteúdo do despacho do parquet com o qual recomendou ao juiz o arquivamento do inquérito policial do Caso:

MM. Juiz. Trata-se de inquérito instaurado para a apuração de eventual delito previsto na Lei n. 7.716 / 89 (Lei Caó), envolvendo Aparecida Gisele [...] Segundo se apurou [ela] fez publicar, no jornal Folha de São Paulo (de 02.03.1997) um anúncio onde demonstrava seu interesse em contratar uma doméstica que, entre outras características, deveria ser preferencialmente da raça branca. É dos autos [do inquérito policial] que após a publicação do anúncio, diversas pessoas entraram em contato com Gisele, ou com a pessoa que a representava para tanto [e que] Simone André Diniz realizou uma ligação para o número indicado no anúncio, sendo certo que a mesma se sentiu discriminada, pelo fato de ser da raça negra e ter sido preterida para a vaga como doméstica. Aparecida Gisele foi ouvida [...] e esclareceu à Autoridade Policial, que em momento algum pretendeu discriminar qualquer raça. Esclareceu que seus filhos haviam tido um problema de

\footnotetext{
${ }^{6}$ No Caso em questão, consideramos como intérpretes do direito o delegado, o promotor e o juiz do caso.
} 
relacionamento com uma doméstica de cor negra, que chegou a espancar os mesmos, o que a motivou, em face de um receio gerado nas crianças, que fosse dada a preferência a uma empregada de cor branca. Esclareceu ainda a averiguada, que não possui qualquer tipo de preconceito racial, até mesmo porque é casada há onze anos com Jorge Honório da Silva, pessoa de raça negra. Como Vossa Excelência pode bem observar, não se logrou apurar nos autos que [a acusada] tenha praticado qualquer ato que pudesse constituir crime de racismo, previsto na Lei 7.716 / 89. Diante do exposto, não havendo nos autos qualquer base para o oferecimento de denúncia, requeiro que Vossa Excelência determine o ARQUIVAMENTO do presente feito, ressalvado a hipótese do art. 18 do C.P.P. (Inquérito Policial de n. 005/97, da 3. ${ }^{\text {a }}$ Delegacia de Polícia de Investigações Sobre Crimes Raciais de São Paulo, p. 25 e 26)

A interpretação da hermenêutica que o promotor deu aos fatos denunciados, por Simone, e a Lei Caó (art. 20) evidência que ele opinou pelo arquivamento do Caso por acreditar que a acusada não agiu com dolo de discriminar (dolo discriminandi) porque que ela era casada com um negro, com qual tinha até filhos. Para o promotor do Caso e o entendimento majoritário das intérpretes do direito da justiça brasileira, o dolo do agente acusado de ter praticado um dos crimes raciais do direito brasileiro ${ }^{7}$, deve ser do tipo contumaz e contundente, típico de um verdadeiro racista - um agente social que reiteradamente discrimina as pessoas de da cor/raça negra. Segundo o promotor, ser casada com um negro, por exemplo, significava que a acusada não tinha com ser racista, e, por essa, praticar os crimes raciais da Lei Caó.

Posteriormente, como manda a lei, o promotor submeteu o seu entendimento e desejo de arquivar o inquérito ao crivo valorativo do juiz que, sem muita resistência, e estar subordinado ("preso") à hermenêutica do parquet sobre a denúncia de Simone e a Lei Caó, se posicionou da seguinte forma:

\begin{abstract}
Vistos: Nos termos do pronunciamento do representante do ministério público, que acolho e adoto como razão de decidir, determino o arquivamento destes autos de Inquérito Policial, sem prejuízo de novas diligências na forma do disposto no artigo 18 do Código de Processo Penal Anote-se, comunique-se e intime-se. (Inquérito Policial de n. 005/97, da 3. ${ }^{a}$ Delegacia de Polícia de Investigações Sobre Crimes Raciais de São Paulo, p. 25 e 26)
\end{abstract}

$\mathrm{Na}$ verdade, o promotor e o juiz "acordaram" pelo arquivamento do inquérito policial porque não havia provas cabais do dolo ("do tipo contumaz e

\footnotetext{
${ }^{7} \mathrm{Na}$ Lei Caó estão tipificados os crimes raciais inafiançáveis e imprescritíveis do direito brasileiro, que são punidos com pena de detenção e multa. No Código Penal, temos o crime de injúria racial, que é afiançável e prescritível. Os crimes da Lei Caó são crimes de natureza pública, o que exige que o ministério público proponha a justiça uma ação penal pública incondicionada em face de quem é acusado de ser um agente racializados. Já o crime de injúria racial só é processado pela justiça se a vítima se manifestar formalmente nesse sentido por meio de um advogado.
} 
contundente") da acusada. Para eles dois, faltaram no inquérito e provas produzidas - os relatos dos envolvidos coletados pela autoridade policial indícios mais robustos (consistentes) sobre o comportamento e os relacionamentos pessoais da acusada que atestassem a sua condição de verdadeira racista. Na opinião (interpretação) do parquet e do juiz, o fato dela ser casada com um negro, com que tinha até filhos, afastava (provava) a existência desse tipo de dolo e, assim, a possibilidade de prová-lo.

Os intérpretes do direito exigem a comprovação do tipo dolo que acabamos de apontar para que uma denúncia de prática de crime racial seja apurada, denunciada, processada e julgada (decidida) pela justiça. Para eles, e consoante os cânones e defensores da ideologia da democracia racial, o fato da acusada viver e ser casada com um negro tornava-a uma pessoa incapaz de ter ou desenvolver o dolo do tipo contumaz e contundente, o que lhe assegurava uma presunção constitucional de inocência inquestionável.

Por não ser uma verdadeira racista e, portanto, portadora de um dolo do tipo contumaz e contundente, a acusada não poderia praticar nenhum dos crimes raciais da Lei Caó, ou de outra lei do direito brasileiro. Sem a comprovação cabal dessa condição subjetiva do agente acusado de prática de racialização criminosa, a denúncia do "racializado" não merece prosperar, ser apurada e julgada (decidida) pela justiça. Por conseguinte, o arquivamento do Caso foi uma medida de justiça porque seguiu o entendimento hegemônico que orienta a "aplicação prática" (mais adequada e justa) do comando da CF/88 que criminalizou a prática do racismo, e dos dispositivos da Lei Caó que tipificaram os crimes raciais inafiançáveis e imprescritíveis do direito brasileiro.

Não é injusto exigir e cobrar a comprovação do dolo do agente, mas sim exigir que ele seja do tipo contumaz e contundente - o que constitui um excesso de interpretação judicial que compromete o acesso à justiça, a justiça e garantia de direitos. Na prática, esse tipo de cobrança torna impossível a tribunalização dos crimes raciais da Lei Caó, já que institui criminalizações que não foram positivadas pelo direito, como, por exemplo, ser um verdadeiro racista - o agente que tem razões, motivações psicológicas e condições para praticar racializações criminosas. O que a Lei Caó, seguindo as determinações da CF/88, criminalizou foi à prática do racismo e não, como entendem os doutrinadores e intérpretes do direito da justiça brasileira, o fato de alguém ser racista. Tanto a CF/88 quanto a Lei Caó, em momento algum, condicionaram a consumação dessa prática delituosa ao fato do agente ser um verdadeiro racista, portador de dolo intenso, cuja vida é marcada por "pistas" de sucessivas e constantes racializações. Portanto, ter que provar essa condição do agente, para aplicar que a Lei Caó seja aplicada ao caso concreto, é uma exigência hermenêutica inconstitucional dos intérpretes do direito da justiça brasileira.

Do ponto de vista histórico e sociológico, a comprovação do dolo contumaz e contundente do agente acusado de ser racializador é muito difícil (quase) impossível de ser obtida entre os brasileiros porque, segundo as tradicionais interpretações sobre o Brasil e os postulados da ideologia da democracia racial, elementos que têm 
muita influência sobre os intérpretes do direito, ele é típico das sociedades centrais e (semi)periféricas onde existiram (ou ainda existem fortes resquícios de) leis e regimes segregacionistas, como o Apartheid (da África do Sul) e o Jim Crow (dos USA). Durante a existência oficial desses regimes - exemplos de verdadeiros racismos e racialização, o acesso à justiça, a obtenção e a garantia dos direitos estavam subordinados ao valor que a cor e a raça das pessoas tinham segundo o discurso oficial que orientava a política de segregação cujo principal postulado era: quanto mais negro, mesmo acesso à justiça, justiça e garantia de direitos. Destacamos que, formalmente, o Estado brasileiro nunca chegou a usar uma segregação tão explicita - altamente legalizada - mas nem por isso deixou de ter mecanismos racializadores efetivos e violentos para excluir as negras e os negros.

A análise do Caso SAD, desenvolvida até o presente momento, demonstra que os intérpretes do direito da justiça brasileira ignoram que o texto da Constituição e da lei (Caó) "mandou" criminalizar a prática do racismo, e não o fato de alguém ser um verdadeiro racista, e que essa ignorância compromete a aplicabilidade e a efetividade dos recursos jurídicos que combatem o racismo e a prática das racializações criminosas.

Por essa razão, é injusto - e inconstitucional - exigir a comprovação de que o agente é portador de um dolo do tipo contumaz e contundente do agente. Essa exigência só seria legítima (justa) se o crime fosse o agente ser um verdadeiro racista, mas, como já destacamos, o crime é praticar o racismo. E, para provar a praticar o racismo, deve se cobrar a prova de um dolo necessário que seja necessário e suficiente para violar a igualdade e/ou comprometer o tratamento igual.

\section{O PEDIDO DE CONDENAÇÃO E A DEFESA DO ESTADO BRASILEIRO}

Para corroborarem a denúncia feita a $\mathrm{CIDH}$, os peticionários do Caso fizeram menção à histórica falta de empenho do Estado brasileiro em combater a posição desprivilegiada das negras e dos negros no Brasil. Segundo dados da ONU e de outros órgãos/instituições que monitoram os direitos humanos, como a própria OEA, no Brasil, os negros e as negras são a maioria entre os que têm menos acesso à educação, às universidades públicas, à justiça, ao mercado formal de trabalho, às funções de comando no Estado e iniciativa privada. Em1996, um ano antes de o Caso aparecer, o Estado brasileiro lançava o seu Programa Nacional de Direitos Humanos para tentar reverter à precária situação dos direitos humanos no, reconhecendo que a falta de acesso à justiça para os negros racializados era um problema sério, que urgia ser enfrentado com mais em empenho e vontade política.

Os estudos de Sério Adorno (1996) sobre a influência negativa que a raça e/ou cor negra exercem sobre os julgamentos dos réus negros, que foram usados como "prova" pelos peticionários do Caso, atestam que eles estão entre os que recebem as condenações mais duras e longas dos tribunais brasileiros. Segundo 
Carlos Antonio Costa Ribeiro (1995), essa propensão institucional da justiça de punir mais os negros do que os brancos, por causa da cor e raça, remonta as primeiras décadas da república quando ser negro implicava em menos acesso à justiça e garantia de direitos - uma singularidade histórica que ainda desafia as determinações e objetivos da Constituição de 1988 e das leis internacionais dos direitos humanos das quais o Estado brasileiro é signatário.

Simone e os peticionários solicitaram à Comissão que o Estado brasileiro fosse condenado: a) pela violação das garantias jurídicas da $\mathrm{CADH}$; b) a dar ampla publicidade ao Caso e as decisões que dele resultassem; c) a pagar uma indenização à Simone A. Diniz, no valor de $\mathrm{R} \$ 55.000,00$; d) a fornecer uma bolsa de estudos que lhe assegurasse o ingresso e a permanência num estabelecimento de ensino superior. Alegaram que o nosso Estado violou as seguintes normas jurídicas: a) artigos art. 8.1, 24 e 25 da Convenção Americana sobre os Direitos do Homem; b) e os art. 1, (a), 5 (a), (i) e 6 da Convenção Internacional para a Eliminação de Todas as Formas de Discriminação Racial da ONU. ${ }^{8}$

Qual foi à defesa do Estado Brasileiro? Alegou que não houve violação da $\mathrm{CADH}$ porque o arquivamento do inquérito e os seus desdobramentos tinham amparo na lei processual e jurisprudência brasileira predominante sobre como os intérpretes do direito devem aplicar as leis de combate a discriminação racial aos casos concretos, que impõem à seguinte "regra": se não há condições para o oferecimento da denúncia, por exemplo, em virtude da não comprovação do dolo ("contumaz e contundente") do agente, o caso deve ser arquivado. Portanto, com base nessa hermenêutica, considerada justa e legítima pelos intérpretes do direito da justiça brasileira, não houve aplicação do direito ao caso concreto que constituísse violação da Lei Caó, da Constituição, prática de tratamento diferenciado, negação de acesso à justiça, ou violação de dispositivos da $\mathrm{CADH}$.

Nessa hipótese, a da não comprovação do dolo (contumaz e contundente) do agente racializador, segundo os argumentos defensivos do Estado brasileiro, não há prática de crime racial porque a conduta do acusado é atípica: não reúne todos os elementos que constituem um crime. Por essa razão, o Estado brasileiro solicitou a Comissão que não aceitasse o caso e, como isso, não apreciasse o seu mérito.

Após analisar os argumentos do Estado denunciado e dos peticionários, a CIDH resolveu aceitar e decidir o Caso. Porém, como é de praxe, estabeleceu um prazo (de três meses) para que as partes chegassem a um acordo - a uma solução amistosa. Isso não aconteceu porque transcorrido esse prazo, o Estado

${ }^{8}$ Essa lei internacional diz no art. I, 1 que discriminação racial "significa qualquer distinção, exclusão, restrição ou preferência, baseadas em raça, cor, descendência ou origem nacional ou étnica que têm por objetivo ou efeito anular ou restringir o reconhecimento, gozo ou exercício em um mesmo plano (em igualdade de condição) de direitos humanos e liberdades fundamentais no domínio político, econômico, social, cultural ou em qualquer outro domínio de vida pública”. Convenção sobre a Eliminação de Todas as Formas de Discriminação Racial da ONU. Disponível em: <http://www.onubrasil.org.br/doc_cs.php>. Acessado em: 17 de janeiro de 2009. 
brasileiro não apresentou uma proposta de acordo a Simone e aos peticionários. Diante da inércia do Estado brasileiro e a pedido dos peticionários, a CIDH a proferiu uma decisão de mérito sobre o Caso.

O primeiro passo nesse sentido foi a Comissão se pronunciar sobre a natureza jurídica dos crimes da Lei Caó, externando que:

Trata-se de tipo penal em que o crime só ocorreria se operasse através de meio de comunicação social ou por intermédio de qualquer publicação [...] Como era crime formal ou de mera conduta, isto é, de consumação antecipada, sua consecução independia dos efeitos que viessem a ocorrer, quer dizer, não havia a necessidade do resultado para que se consumasse o crime. Praticar a preferência [por cor e/ou raça] já seria suficiente para se concretizar o crime. Os peticionários denunciaram também que, concluído

Inquérito

Policialhttp://www.cidh.org/annualrep/2006port/BRASIL.12001p ort.htm - _ftn59 este foi remetido ao Ministério Público para que este órgão iniciasse a ação penal pertinente, uma vez que a Lei $7716 / 89$, tipifica crimes cuja titularidade da ação pertence ao Ministério Público. De maneira que, em razão do principio da obrigatoriedade, bastavam estar presentes no inquérito, indícios de autoria e materialidade para o Ministério Público estar legitimado e obrigado a instaurar a denúncia penal pertinente [ $e$ que] http://www.cidh.org/annualrep/2006port/BRASIL.12001 port.htm - _ftn60tem conhecimento que a lei processual penal brasileira estabelece que o Ministério Público poderá pedir o arquivamento de uma denúncia penal quando não encontrar elementos que possam indicar a ocorrência de crime e o juiz, apesar de não estar obrigado,http://www.cidh.org/annualrep/2006port/BRASIL.12001 port.htm - _ftn61 poderá determinar esse arquivamento. Entretanto, tal decisão não pode ser incongruente com o comando constitucional brasileiro que garante a apreciação do Judiciário para toda lesão ou ameaça a direito. http://www.cidh.org/annualrep/2006port/BRASIL.12001port.htm

- _ftn62 Como também não pode ferir o comando convencional que garante a toda pessoa não somente o direito a um recurso efetivo, mas também o direito ao desenvolvimento da possibilidade de recurso judicial [já que] houve um anúncio discriminatório publicado por um meio de comunicação e sobre isso uma pessoa afro-descendente [negra] apresentou uma denúncia e a determinação efetuada pelo Ministério Público lhe impediu de aceder a um recurso judicial efetivo que a tutelasse em seu direito a não ser discriminada [...] o Estado brasileiro está obrigado, não somente por instrumentos internacionais que ratificou, mas também pela sua própria constituição, a administrar justiça aos seus cidadãos toda vez que for invocada a tutela jurisdicional

Estado.http://www.cidh.org/annualrep/2006port/BRASIL.12001p ort.htm - _ftn63 À obrigação doméstica de investigar, julgar e sancionar os crimes de motivação racial, soma-se a obrigação internacional advinda da ratificação de tratados sobre a matéria que coloca o direito de não ser discriminado no grupo de normas imperativas do direito internacional dos direitos humanos que são 
absolutas, inderrogáveis e não sofrem modificação. (Caso Simone André Diniz. Relatório de Mérito. OEA/CIDH 2006)

\title{
A CIDH ainda lembrou que
}

$\mathrm{O}$ artigo $6^{\circ}$ a Convenção Internacional sobre a Eliminação de Todas as Formas de Discriminação Racial, ratificada pelo Brasil [...] utilizada como pauta interpretativa, estabelece um padrão que assegura especificamente às vitimas de discriminação racial proteção e recurso efetivo junto aos tribunais internos, nos termos seguintes: Os Estados-Partes assegurarão às pessoas sujeitas a sua jurisdição proteção e recurso efetivos aos tribunais nacionais e outros organismos do Estado competentes, contra todos os atos de discriminação racial que, contrariando a presente Convenção, violem os seus direitos individuais ou as liberdades fundamentais, assim como o direito de pedir a esses tribunais satisfação ou reparação, justa e adequada, por qualquer prejuízo de que sejam vitimas em razão de tal discriminação. (Caso Simone André Diniz. Relatório de Mérito. OEA/CIDH 2006)

\section{A DECISÃO DE MÉRITO DA CIDH SOBRE O CASO}

\author{
No dia 21 de outubro de 2006, a Comissão concluiu que
}

Da análise dos fatos denunciados denota-se a inaplicabilidade da Lei 7.716/89, em razão da denegação de um recurso efetivo para levar à apreciação do poder judiciário a lesão ao direito de não ser discriminado [...] A Corte (Interamericana dos Direitos Humanos) reiterada vezes assinalou que não franquear ao lesionado o direito de acesso à justiça [viola] os padrões convencionais: a inexistência de um recurso efetivo contra as violações aos direitos reconhecidos pela Convenção constitui uma transgressão da mesma pelo Estado Parte no qual semelhante situação tenha lugar. Nesse sentido, deve-se salientar que, para que tal recurso exista, não basta que esteja previsto pela Constituição ou pela lei ou que seja formalmente admissível, mas sim se requer que seja realmente idôneo para estabelecer se incorreu em uma violação aos direitos humanos e prover o necessário para remediá-la. Não podem ser considerados efetivos aqueles recursos que, pelas condições gerais do país ou inclusive pelas circunstâncias particulares de um dado caso, resultem ilusórios. Isso pode ocorrer, por exemplo, quando sua inutilidade tenha ficado demonstrada pela prática, porque o Poder Judicial carece da independência necessária para decidir com imparcialidade ou porque faltam os meios para executar suas decisões; por qualquer outra situação que configure um quadro de denegação de justiça, como sucede quando se incorre em retardamento injustificado na decisão; ou, por qualquer causa, não se permita ao presumível lesionado o acesso ao recurso judicial. (Caso Simone André Diniz. Relatório de Mérito. OEA/CIDH 2006) http://www.cidh.org/annualrep/2006port/BRASIL.12001 port.htm -_ftn66 


\section{Por ter violado os artigos 8.1 e 24 e 25 da $\mathrm{CADH}^{9}$ e não ter apurado corretamente a denúncia de racialização feita por Simone, a CIDH "condenou" o Estado Brasileiro a cumprir 12 recomendações, a saber:}

1) Reparar plenamente a vítima Simone André Diniz, considerando tanto o aspecto moral como o material, pelas violações de direitos humanos determinadas no relatório de mérito e, em especial; 2) Reconhecer publicamente a responsabilidade internacional por violação dos direitos humanos de Simone André Diniz; 3) Conceder apoio financeiro à vítima para que esta possa iniciar e concluir curso superior; 4) Estabelecer um valor pecuniário a ser pago à vítima a título de indenização por danos morais; 5) Realizar as modificações legislativas e administrativas necessárias para que a legislação antiracismo seja efetiva, com o fim de sanar os obstáculos demonstrados nos parágrafos [...] do presente relatório; 6) Realizar uma investigação completa, imparcial e efetiva dos fatos, com o objetivo de estabelecer e sancionar a responsabilidade a respeito dos fatos relacionados com a discriminação racial sofrida por Simone André Diniz; 7) Adotar e instrumentalizar medidas de educação dos funcionários de justiça e da polícia a fim de evitar ações que impliquem discriminação nas investigações, no processo ou na condenação civil ou penal das denúncias de discriminação racial e racismo; 8) Promover um encontro com organismos representantes da imprensa brasileira, com a participação dos peticionários, com o fim de elaborar um compromisso para evitar a publicidade de denúncias de cunho racista, tudo de acordo com a Declaração de Princípios sobre Liberdade de Expressão; 9) Organizar Seminários estaduais com representantes do Poder Judiciário, Ministério Público e Secretarias de Segurança Pública locais com o objetivo de fortalecer a proteção contra a

${ }^{9}$ Essa Convenção nesses dispositivos institui que: 1) toda pessoa tem direito a ser ouvida, com as devidas garantias, e dentro de um prazo razoável, por um juiz ou tribunal competente, independente e imparcial, estabelecido anteriormente por lei, na apuração de qualquer acusação penal formulada contra ela, ou para que se determinem seus direitos ou obrigações de natureza civil, trabalhista, fiscal ou de qualquer outra natureza; (2) Toda pessoa acusada de delito tem direito a que se presuma sua inocência enquanto não se comprove legalmente sua culpa. Durante o processo, toda pessoa tem direito, em plena igualdade, às seguintes garantias mínimas: a) direito do acusado de ser assistido gratuitamente por tradutor ou intérprete, se não compreender ou não falar o idioma do juízo ou tribunal; b) comunicação prévia e pormenorizada ao acusado da acusação formulada; c) concessão ao acusado do tempo e dos meios adequados para a preparação de sua defesa; d) direito do acusado de defender-se pessoalmente ou de ser assistido por um defensor de sua escolha e de comunicar-se, livremente e em particular, com seu defensor; e) direito irrenunciável de ser assistido por um defensor proporcionado pelo Estado, remunerado ou não, segundo a legislação interna, se o acusado não se defender ele próprio nem nomear defensor dentro do prazo estabelecido pela lei; f) direito da defesa de inquirir as testemunhas presentes no tribunal e de obter o comparecimento, como testemunhas ou peritos, de outras pessoas que possam lançar luz sobre os fatos; g) o direito de não ser obrigado a depor contra si mesma, nem se declarar culpada; e h) direito de recorrer da sentença para juiz ou tribunal superior. (3) A confissão do acusado só é válida se feita sem coação de nenhuma natureza. (4) $\mathrm{O}$ acusado absolvido por sentença passada em julgado não poderá ser submetido a novo processo pelos mesmos fatos. (5) O processo penal deve ser público, salvo no que for necessário para preservar os interesses da justiça. Convenção Americana sobre os Direitos Humanos. Disponível em: <http://www.oas.org/juridico/portuguese/carta.htm>. Acesso em: 09 de agosto de 2009. 
discriminação racial e o racismo; 10) Solicitar aos governos estaduais a criação de delegacias especializadas na investigação de crimes de racismo e discriminação racial; 11) Solicitar aos Ministérios Públicos Estaduais a criação de Promotorias Públicas Especializadas no combate a discriminação racial e ao racismo; 12) Promover campanhas publicitárias contra a discriminação racial e o racismo. (Caso Simone André Diniz. Relatório de Mérito. OEA/CIDH 2006)

No próximo capítulo, com base no que já dissemos sobre o Caso, apresentaremos ao nosso leitor o que deve ser ensinado sobre o combate judicial das racializações criminosas e as razões da falta de acesso à justiça para as negras e os negros que são racializados. A análise do Caso não deixa dúvidas sobre a existência de um fenômeno, que merece mais atenção dos estudiosos do direito: a relação que há entre a falta de acesso à justiça e as hermenêuticas que os intérpretes do direito produzem e usam para justificar a aplicação (ou não) da Lei Caó as denúncias de prática de racialização criminosa.

\section{O QUE ENSINAR A PARTIR DA ANÁlISE DO CASO SOBRE A FALTA DE ACESSO À JUSTIÇA PARA AS VÍTIMAS DOS CRIMES RACIAIS DA LEI CAÓ}

A análise do conteúdo das considerações que a CIDH teceu sobre o Caso, vão de encontro à literatura produzida por Abdias Nascimento (1978), Florestan Fernandes (1972/1978), Jorge da Silva (1994), Lilia M. Schwarcz (1993) e George R. Andrews (1998) sobre as nossas relações e conflitos raciais, na qual encontramos "pistas" sobre a má qualidade do tratamento jurídico que os intérpretes do direito dispensam ao racismo e as denuncias de práticas de racializações criminosas. Nessa literatura, há uma singularidade sobre o Brasil, as nossas relações raciais e crimes raciais, que não escapou da apreciação da CIDH sobre o Caso: muito embora o Brasil seja conhecido mundialmente como um paraíso para todas as raças, cores e culturas, que até possui leis contra o racismo e a racialização de negros, as denúncias de violação dessas leis tradicionalmente são ignoradas ou tratadas inadequadamente pelos intérpretes do direito da justiça brasileira.

O Caso evidencia que as hermenêuticas jurídicas que os intérpretes do direito dispensam à Lei Caó e às denúncias de prática de racialização criminosa negam as negras e aos negros o direito a isologia - um direito essencial a garantia dos direitos fundamentais e humanos. Segundo I. F. Stone, isologia é "o direito de todos à palavra, à expressão de um pensamento" (1988, p.14). Essa negação faz com que, entre os iguais, existam os mais iguais. Esses são os que têm direito a palavra mais forte para denunciar, ou resistir às denúncias; os mais inocentes, cuja defesa já se está assegurada por premissas ideológicas, mitos e dogmas que, mesmo contra o texto legal, influenciam nas decisões e valorações dos intérpretes do direito com as quais, por exemplo, estabelecem que um agente acusado de racialização não possa praticar um crime racial da Lei Caó (ou de outro diploma legal) porque é negro, ou tem relações afetivas mais 
íntimas com os negros, ou negras - o que aconteceu no Caso SAD, a pedido do ministério público.

Essa falta de isologia entre os negros e os brancos faz com que os iguais perante a lei, tornem-se desiguais na sua aplicação, acesso à justiça e garantia dos direitos. A desigualdade gerada por essa falta de isologia torna as denúncias dos negros racializados menos confiáveis do que as versões apresentadas pelos seus algozes porque transforma os relatos desses últimos, ou as interpretações jurídicas que lhes são favoráveis, em verdades inquestionáveis por terem conteúdos narrativos mais compatíveis, por exemplo, com os postulados da ideologia da democracia racial. Isso explica o parquet ter produzido uma hermenêutica da Lei, dos fatos e da denúncia de Simone A. Diniz mais favorável à acusada, e o juiz aceitá-la e usá-la, sem resistências, para fundamentar a sua decisão de arquivar o inquérito do Caso; fato que é reflexo de uma rotina institucional racializadora: o arquivamento sistemático e indevido de inquéritos policiais que narram à prática de racialização criminosa.

O Caso não deixas dúvidas de que a ideologia da democracia racial tem muita influência sobre o trabalho intelectual dos intérpretes/aplicadores do direito porque, ao eufemizar as denúncias de práticas de racialização criminosa e fortalecer a defesa dos acusados, compromete a judiciabilidade das violações dos direitos humanos, um fenômeno que tem repercussões negativas sobre a aplicabilidade e a efetividade desses direitos.

Os estudos de José Ricardo Cunha (2005) sobre a judiciabilidade das violações dos direitos humanos - entre os quais estão as garantias jurídicas que primam pela efetiva garantia da igualdade de tratamento e oportunidades ensinam que a aplicabilidade e a efetividade desses mesmos direitos dependem do grau de cognição que os intérpretes do direito têm sobre o que eles são, o que significam, como aplicá-los/garanti-los e ensiná-los da forma mais adequada justa possível. Em pesquisa empírica, feita junto a intérpretes do direito do TJ/RJ - juízes e promotores, José Ricardo Cunha (2005) constatou que os direitos humanos não são muito conhecidos, pelos intérpretes do direito desse tribunal uma realidade que vale para os demais cortes judiciais brasileiras. Ao longo da formação técnica e profissional dos intérpretes do direito os estudos sobre os direitos humanos não recebem a atenção e tempo que deveriam receber dos estudantes e professores de direito, gerando sobre eles uma ignorância quase crônica.

Essa constatação e o estudo do Caso apontam para um diagnóstico preocupante: o pouco conhecimento e o fraco ensino desses diretos - nos quais há garantias que protegem os negros de discriminações raciais criminosas e de outra natureza - favoreçam a criação de rotinas institucionais e hermenêuticas/aplicações racializadoras da Constituição e da Lei Caó que, na prática, negam acesso à justiça a quem é "preterido" em virtude da raça e/ou da cor.

Interpretar que um(a) suposto(a) agente racializador(a) por ser (da raça/cor) negra, ou casado(a) com um(a) negro(a), é incapaz de praticar os 
crimes raciais da Lei Caó - a "tese hermenêutica" produzida e apresentada pelo promotor ao juiz para que ele arquivasse o Caso - o que aconteceu exemplifica e substancializa a força que a ideologia da democracia racial tem para produzir hermenêuticas legais e decisões judiciais que são favoráveis a perpetuação dos seus propósitos: esconder que existe racismo de verdade no Brasil; ocultar que não há acesso efetivo à justiça (e justiça) para as negras e os negros que são discriminados por causa da cor e/ou raça; evitar discussões mais profundas e críticas sobre as razões da pouca efetividade e aplicabilidade dos direitos dos negros; não deixar transparecer que os intérpretes do direito têm uma grande parcela de responsabilidade na falta de acesso à justiça para as vítimas dos crimes raciais da Lei Caó por causa da forma como interpretam e aplicam (usam) a Lei Caó aos casos concretos de denúncia de racialização criminosa; tornar natural (normal) todas essas injustiças.

Com base nos ensinamentos sócio-jurídicos de Eugen Ehrlich (1986) sobre as singularidades do tempo passado que condicionam e aprisionam o direito do presente, repercutindo na sua interpretação e aplicação aos casos concretos, defendemos que a falta de acesso à justiça para as negras e os negros racializados tem origem no seguinte fenômeno: desde os anos 50, o Brasil vem criando leis textualmente comprometidas com um futuro mais igual e igualitário para seus jurisdicionados, mas, no tempo presente, a cultura jurídica e a mentalidade dos intérpretes do direito da justiça brasileira ainda estão aprisionadas a um passado no qual a discriminação racial dos negros e das negras sempre ficava impune, ou era, sistematicamente, ignorada pelas autoridades porque não era vista e tratada como uma verdadeira injustiça, que deveria ser efetivamente combatida pela justiça.

Por essa razão a adesão aos tratados dos direitos humanos internacionais e a criação de leis internas mais severas para tratar o racismo e combater a prática de racializações criminosas, por si só, não geram ou significam mais acesso à justiça e justiça para quem sofre com o Du Dois (1999) chamou de barreiras raciais. No nosso entendimento, essas barreiras são representadas pelas discriminações por conta da cor e da raça (negra) que comprometem as garantias constitucionais da igualdade e do tratamento igual. O Caso mostrou e provou que os intérpretes do direito da justiça brasileira "se fecham em copas" quando são acionados para decidir se o poder judiciário vai (ou não) tribunalizar uma denúncia de prática de racialização criminosa. A força normativa da ideologia da democracia racial faz com que esses intérpretes produzam rotinas institucionais e hermenêuticas legais que, na prática, modificam o sentido e o conteúdo das leis e denúncias de racialização, como considerar (interpretar) que o crime é ser racista, e não prática o racismo. Isso faz com que o judiciário absorva poucos casos de racialização criminosa, o que cria a impressão (falsa) de que ele e os seus colaboradores, como o ministério público, não são sensíveis as barreiras da cor e da raça.

\section{CONCLUSÃO}


A análise do Caso indica que uma parcela bem significativa dos intérpretes do direito da justiça brasileira usa os recursos criativos da hermenêutica jurídica, atividade que resulta na aplicação (uso prático) do direito ao caso concreto, para dificultar ou impedir a tribunalização (judicialização) dos crimes raciais e racializações institucionais. Essa tendência, que gera rotinas institucionais racializadoras, favorece aos agentes que são acusados de prática de racialização criminosa. Caso contrário, não haveria um processo hermenêutico hegemônico da Lei Caó, por parte dos intérpretes do direito da nossa justiça, que, contrariando a determinação textual da Constituição de 88, subordina à aplicação dos dispositivos dessa lei à produção de provas que atestem o dolo contumaz e contundente do agente - um tipo de prova que deve ser questionada, já que o crime é praticar o racismo, não ser um verdadeiro racista.

O Caso prova que há regiões (semi)periféricas na Carta de 88 e no atual sistema legal brasileiro, nas quais estão positivados os direitos humanos e os direitos dos negros. Essas regiões são os "locais" onde estão (concentrados e confinados) os direitos e garantias que, embora válidos e vigentes, não têm efetividade devido à falta de empoderamento dos seus titulares, um fenômeno que decorre, dentre outras razões, da histórica posição sócio-econômica menos privilegiada da população negra do Brasil - um dado bastante divulgado pelo IPEA e o IBGE ${ }^{10}$.

Ao lado dessas regiões, contribuindo ainda mais para a inefetividade e a pouca aplicabilidades dos direitos e garantias dos negros, estão os (semi)periferismos constitucionais: as práticas jurídicas, os hábitos, os costumes, as concepções de justiça/justo, hermenêuticas legais e usos práticos dos direitos que fomentam a produção de rotinas institucionais que negam e/ou dificultam o acesso à justiça e a garantia dos direitos de certos indivíduos e grupos, historicamente excluídos do universo da cidadania. Bom exemplo, de (semi)periferismo, detectado com a análise do Caso, é um "profissional do direito" da justiça brasileira considerar (interpretar) que um agente não pratica (ou pode praticar) um crime racial da Lei Caó - ou de outra legislação - porque é casado(a) com um(a) negro(a). Ao menor sinal de simpatia pretérita do acusado em relação ao negro e a comunidade negra, segundo o que depreendemos da decisão da $\mathrm{CIDH}$, os intérpretes do direito da justiça brasileira "acordam" o arquivamento da denúncia do racializado. Relembramos que essa hermenêutica eufemizadora - foi produzida e defendida pelo próprio parquet e, sem reservas, aceita pelo juiz para fundamentar o arquivamento do inquérito policial, o que deu origem ao Caso SAD. Isso prova que o promotor e juiz agiram como verdadeiros advogados da ideologia da democracia racial.

10 Instituto de Pesquisa Econômica Aplicada e Instituto Brasileiro de Geografia e Estatística respectivamente dois órgãos do governo federal responsáveis pelo levantamento de dados que contribuem para a formulação e avaliação das políticas públicas. Com base nos dados coletados por esses órgãos, o governo formula as suas estratégias e políticas públicas de combate a pobreza, a fome e a certas doenças. 
$\mathrm{Na}$ verdade, os intérpretes do direito da justiça brasileira estabeleceram uma hermenêutica (aplicação) injusta ("inconstitucional") da Lei Caó e da norma da $\mathrm{CF} / 88$ que criminalizou a prática do racismo: o crime é ser racista, não praticar o racismo. Isso acontece porque a ideologia da democracia racial e a sua força normativizadora fazem com que os intérpretes/aplicadores do direito discutam e decidam se o acusado é ou não um verdadeiro racista - o que não é crime, e nunca foi, e não se ele, realmente, praticou uma racialização criminosa do direito penal brasileiro. Por essa razão, os promotores e os juízes, em especial, valorizam muito o histórico passado e presente de não racista (não racializador) do acusado nos quais há indicações narrativas de que ele tem (ou teve) filhos negros, parentes negros, relacionamentos íntimos com negros e apreço pelas coisas de negros, como cultura e religião.

A análise do Caso SAD prova que o acesso à justiça no Brasil é (e sempre foi) muito sensível à raça e a cor dos negros - quanto mais branco é o agente, mais acesso à justiça e garantia de direitos ele tem, ou tende a ter. Para os membros da comunidade negra, o acesso à justiça é muito restrito porque no conteúdo das denúncias de racialização, que eles apresentam às autoridades da justiça, está uma realidade que o Brasil e os brasileiros não querem admitir que exista: a prática de ação humana ou comportamento institucional que macula as idéias e mitos da ideologia da democracia racial, em especial, a crença em uma suposta cordialidade dos nossos racismos institucionais e práticas racializadoras.

Segundo as considerações da CIDH, essa situação é agravada pela questão do gênero, já que as mulheres negras do Brasil, segundo informaram os peticionários do Caso, têm menos acesso à justiça do que os homens negros e as mulheres brancas. Essa sensibilidade, em nossa opinião, existe e se perpetua porque os intérpretes do direito da justiça brasileira absorveram - uns mais outros menos - os postulados da ideologia da democracia racial, ao quais formam um conjunto de ideias, crenças e mitos cujo propósito é enfraquecer a luta contra o racismo institucional, dentro ou fora dos tribunais brasileiros, e a sistemática falta de punição dos crimes raciais. Acreditamos que essa absorção será só combatida se for mais estudada e discutida pelos próprios intérpretes e estudiosos do direito. O estudo e a discussão dos efeitos da absorção dos postulados da ideologia da democracia racial exigirão esses intérpretes do direito dialoguem mais com outros campos do conhecimento humano, como a história, a sociologia e psicologia, nos quais há mais estudos sobre os efeitos jurídicos da baixa aplicação e pouca efetividade das leis brasileiras que criminalizam a prática da racialização criminosa.

As considerações da CIDH sobre o Caso indicam aos defensores e estudiosos dos direitos humanos a existência de rotinas institucionais racializadoras que comprometem o acesso à justiça para as vítimas dos crimes raciais da Lei Caó. As denúncias que narram a prática desses crimes, depois de apresentadas às autoridades competentes para investigá-las, processá-las e julgá-las, sofrem uma verdadeira "metamorfose jurídica": recebem 
hermenêuticas e "tratamentos jurídicos" dos intérpretes do direito que as transformam em crimes mais leves, ou, então, em práticas de ações não criminosas (as chamadas condutas atípicas). Nos dois casos, há grande favorecimento jurídico e processual para os acusados e, também, o embranquecimento sistemático das causas, raças e cores que serão atendidas pela justiça.

Paulo Plutarco de Azevedo ao discorrer sobre as relações que existem entre a aplicação do direito, o contexto social e a ideologia defende que "o pensamento ideológico, não podendo alterar a realidade, altera-lhe a compreensão, e em consequência, o significado" (Plutarco, 2000, p.210). A realidade, no caso, é o direito (a Lei Caó) que, por força da determinação da $\mathrm{CF} / 88$, criminalizou a prática do racismo, não o fato de alguém ser racista. E, essa realidade é um dado que os intérpretes do direito da justiça brasileira não têm poder para mudar, ou extinguir, por mais que não concordem com a sua existência, e por mais que o considerem injusto e até desnecessário para combater a discriminação. Porém, esses mesmos intérpretes podem dar um sentindo (significado) prático a essa realidade, para determinar o que é e quando ocorre à prática do racismo (uma racialização criminosa), como aconteceu no Caso, que não assegura ou dificulta o acesso à justiça para quem padece com a discriminação racial.

O Caso revelou que a ideologia da democracia racial tem muita força para ditar os rumos da justiça e os conteúdos das hermenêuticas que os intérpretes do direito produzem para determinar e legitimar qual é a aplicação prática correta (constitucional e justa) da legislação que positivou os crimes raciais inafiançáveis e imprescritíveis do direito brasileiro. Sem a força dessa ideologia, a imagem de um Brasil sem racismos, racistas e conflitos raciais abertos (violentos) - dogmas que integram a identidade e o ser dos brasileiros - não se sustenta. Sem ela e a sua força, fica fácil perceber que a falta de acesso à justiça para os negros e a inefetividade do direito para combater a racialização e os crimes raciais não são "coisas" naturais, normais e justas, mas reflexos de rotinas institucionais racializadoras dos órgãos da justiça, que se movem e se materializam no mesmo sentido e direção das hermenêuticas das intérpretes do direito. Por essa razão, Clóvis Moura ensina que a idéia de que o Brasil foi e é uma democracia racial nasceu

a partir da necessidade de o colonizador português estabelecer dobradiças amortecedoras das contradições raciais que se apresentavam como ameaça de conflito social e racial permanente [...] Somente a partir das pesquisas financiadas pela UNESCO, após a Segunda Guerra Mundial, essas generalidades otimistas e ufanistas foram revistas com rigor científico e reanalisadas. Uma dessas generalidades refere-se, constantemente, à existência de uma democracia racial no Brasil, exemplo que deveria ser tomado como paradigma para outras nações. Nós éramos [e ainda somos] o laboratório onde se consegui uma solução para os problemas étnicos em sentido planetário. Os resultados dessas pesquisas, no entanto, foram chocantes para os adeptos dessa filosofia racial. Constatou-se que o brasileiro é altamente preconceituoso e o mito da democracia é uma ideologia arquitetada para esconder uma 
realidade social altamente conflitante e discriminatória no nível de relações interétnicas [...] Verificou-se, ao contrário, que os níveis de preconceito eram muito altos e o mito da democracia racial era mais um mecanismo de barragem à ascensão da população negra aos postos de lideranças ou prestígio quer social, cultural ou econômico. (MOURA, 1988, p. 36)

Enquanto a força normativizadora dessa ideologia não for combatida e criticada pelos intérpretes e estudiosos o direito, a garantia e o ensino dos direitos (humanos e dos negros) não serão levados a sério pelos intérpretes/aplicadores do direito que atuam na distribuição e administração da justiça. Essa ideologia coloca o estudo, a pesquisa e a crítica sobre as razões da falta de acesso à justiça para os negros racializados na (semi)periferia do ensino jurídico e das discussões que amimam a vida intelectual (e profissional) dos intérpretes do direito, o que, como alertamos, contribui para comprometer a aplicação e efetividade dos direitos dos negros.

A influência da ideologia de democracia racial, segundo as nossas interpretações sobre a decisão da CIDH e o Caso, faz com que os intérpretes do direito ignorem ou menosprezem três realidades contrárias as determinações da Constituição de 88: (1) a grande força do racismo institucional da justiça brasileira; (2) a sistemática falta de punição dos crimes raciais; (3) o crime é a prática o racismo, não ser um "racista verdadeiro". Quanto mais analisarmos esses sintomas, mais saberemos sobre como a ideologia da democracia racial fomenta a criação de hermenêuticas, aplicações do direito e rotinas institucionais que negam o acesso à justiça para quem é racializado em virtude de prática de preconceito de cor e raça, que a lei tipifica como crime.

Precisamos estudar e criticar mais os efeitos que a ideologia da democracia racial tem sobre a hermenêutica e a aplicação do direito aos casos concretos de denúncia de racialização criminosa, já que o Caso demonstrou que ela pode produzir entendimentos possíveis sobre o direito que não contribuem para garantir acesso à justiça (e justiça) às negras e aos negros racializados.

Nenhum direito tem um único significado, interpretação e forma exclusiva de ser aplicado a um caso concreto. Porém, entre as possíveis hermenêuticas (interpretações) e aplicações do direito existem as que servem mais (e melhor) para garantir justiça, acesso À justiça e direitos - um propósito da democracia e do Estado democrático de direito; e as que servem mesmo ou dificultam a realização desse mesmo propósito.

A análise do Caso SAD mostrou que a ideologia da democracia racial institui um fenômeno que permeia o cotidiano da justiça brasileira e dos intérpretes do direito: a produção sistemática de rotinas institucionais e hermenêuticas - do direito e das denúncias de racialização - que naturalizam e legitimam à falta de acesso à justiça para quem sofre discriminação por conta da cor e/ou raça. Como exemplo e prova do que foi dito, lembramos que a origem do Caso remonta ao seguinte fato: segundo a CIDH, os profissionais do direito da justiça brasileira, interpretarem como legal e justo (constitucional) a vítima 
de uma racialização criminosa ter que provar a condição de verdadeiro racista do agente acusado, quando o denuncia formalmente à polícia. Se isso não acontecer, eles arquivam a denúncia por ausência de conduta típica do agente, como aconteceu com Simone (a protagonista do Caso).

As pesquisas sobre o racismo e a racialização no Brasil devem intensificar as suas críticas e análises sobre as rotinas institucionais e hermenêuticas, já tradicionais e hegemônicas, que estão ligadas a interpretação e aplicação da Lei Caó. Acreditamos que essas pesquisas contribuirão para mostrar, a médio e longo prazo, como e quanto os intérpretes do direito da justiça brasileira são responsáveis pela racialização institucional da "gente de cor". Cremos que o primeiro paço a ser dado, na direção da intensificação dessas pesquisas, será cobrar das faculdades de direito que destinem mais espaços, recursos e oportunidades para quem deseja estudar (pesquisar) porque o Brasil tem tantos recursos jurídicos contrários ao racismo institucional e a prática dos crimes raciais que são inefetivos. Outra solução poderia ser o Estado estimular a criação de mais programas e linhas de pesquisas nos cursos de pós-graduação em direito fuçadas no estudo da legislação brasileira de combate ao racismo e aos crimes raciais. Esses são e serão os grandes reptos de quem milita em prol dos direitos humanos no nosso país. Enquanto não eles forem superados, nunca conheceremos bem e desvendaremos um segredo: porque o Brasil tem leis duras contra o racismo e a prática da racialização que não garantem acesso efetivo à justiça para as negras e os negros porque têm pouca aplicação e efetividade.

\section{REFERÊNCIAS}

ABREU, Sérgio. Os descaminhos da tolerância: o afro-brasileiro e o princípio da igualdade e da isonomia no Direito Constitucional. Rio de Janeiro: Lúmen Júris, 1999.

ADORNO, Sérgio. Racismo, criminalidade e justiça penal: réus brancos e negros em perspectiva comparativa. Estudos Históricos. Fundação Getúlio Vargas, Rio de Janeiro, p. 284 - 285. 1996.

ALBUQUERQUE, Roberto Cavalcanti de. Gilberto Freyre e a invenção do Brasil. Rio de Janeiro: José Olímpio, 2000.

ANDREWS, George Reid. Negros e brancos em São Paulo. São Paulo: Edusc, 1988.

ARANTES, Paulo Tarso Lugo. O Caso Simone André Diniz e a luta contra o racismo estrutural no Brasil. Direito, Estado e Sociedade n. 31, jul / dez 2007.

AZEVEDO, Plauto Faraco de. Aplicação do direito e contexto social. 2. ed. São Paulo: Revista dos Tribunais, 2000.

BITENCOURT, Cezar Roberto. Manual de Direito Penal, V2. São Paulo: Saraiva, 2001.

BOIS, W. E. B. As almas da gente negra. Rio de Janeiro: Lacerda, 1999. 
CAPPELLETTI, Mauro; GARTH, Bryant. Acesso à justiça. Porto Alegre: Sergio Antonio Fabris Editor, 1988.

CASHMORE, Ellis. Institutional Racism. In: CASHMORE, Ellis (org.). Dictionary of Race and Ethnic Relations. London: Routlege, 1996.

CASO Simone André Diniz. Relatório de Mérito. OEA/CIDH. 2006. Disponível em: <SAD http://www.cidh.org/annualrep/2006port/BRASIL.12001port.htm>. Acessado em: 27 de fevereiro de 2009.

CUNHA, José Ricardo. Derechos humanos y justiciabilidad: uma investigatión em

Rio de Janeiro. Revista Sur. Número 3. Ano 2, 2005.

CHACON, Vamireh. A construção da brasilidade. Brasília: Paralelo 15 / São

Paulo: Marco Zero, 2001.

CONVENÇÃO Interamericana dos Direitos Humanos. Disponível em:

$<$ <ttp://www.cidh.oas.org/Basicos/Portugues/c.Convencao_Americana.htm>. Acesso em: 11 de maio de 2009.

CONVENÇÃO sobre a Eliminação de Todas as Formas de Discriminação Racial da ONU. Disponível em: <http://www.onu-brasil.org.br/doc_cs.php>. Acessado em: 17 de janeiro de 2009.

CONVENÇÃO 111 da OIT. Disponível em:

$<$ http://www.direitoshumanos.usp.br/index.php/OIT-Organiza\%C3\%A7\%C3\%A3oInternacional-do-Trabalho/convencao-sobre-a-discriminacao-em-emprego-eprofissao-1958-no-111.html>. Acesso em: 08 de agosto de 2009.

DECLARAÇÃO de Direitos Humanos da ONU. Disponível em: < http://www.onubrasil.org.br/documentos_direitoshumanos.php>. Acesso em: 12 de maio de 2009.

DUARTE, Evandro Charles Piza. Criminologia \& racismo. Curitiba: Juruá, 2006.

EHRLICH, Eugen. Fundamentos da Sociologia do Direito. Brasília: UNB, 1986.

ESTATUTO da Comissão Interamericana de Direitos Humanos. Disponível em: <http://www.oas.org/juridico/portuguese/carta.htm>. Acesso em: 8 ago. 2009.

FAUTOS, Boris. O Crime do restaurante chinês: carnaval, futebol e justiça na São Paulo dos anos 30. São Paulo: Companhia das Letras, 2009.

FERNANDES, Florestan. O negro no mundo dos brancos. São Paulo: Difusão Européia do Livro, 1972.

FREYRE, Gilberto. Interpretação do Brasil. Lisboa: Livros do Brasil. Limitada [s/d];

Casa Grande \& Senzala. $30^{\circ}$. Ed. Rio de Janeiro: Editora Record, 1995;

GUIMARÃES, Antonio Sérgio Alfredo. Preconceito e discriminação. São Paulo: Editora 34, 2004.

INQUÉRITO Policial de n. 005 / 97 da 3ª Delegacia de Polícia de Investigações

Sobre Crimes Raciais da Secretária Estadual de Segurança do Estado de São Paulo, p. $25,26$.

JESUS, Damásio. Direito Penal. V. 2. São Paulo: Saraiva, 2006. 
LAVORENTI, Wilson. Crimes resultantes de preconceito de raça e de cor: Lei 7.716 / 89. In: GENOFRE, F.; LAVORENTI, W.; SILVA, J. G. (orgs). Leis Penais

Especiais Anotadas. 9. ed. Campinas: Millennium Editora, 2006.

MOURA, Clovis. Sociologia do Negro Brasileiro. São Paulo: Ática, 1988.

NASCIMENTO, Abdias do. O genocídio do negro brasileiro: processo de um racismo mascarado. Rio de Janeiro: Paz e Terra, 1978.

PACTO Internacional dos Direitos Civis e Políticos. Disponível em:

$<$ http://www.mj.gov.br/sedh/ct/legis_intern/pacto_dir_politicos.htm>. Acesso em: 17 de maio de 2009.

PIOVESAN, Flávia. Direitos humanos e justiça internacional. São Paulo: Saraiva, 2007.

Direitos humanos e o direito constitucional internacional. São Paulo:

Saraiva, 2008.

PLANO Nacional dos Direitos Humanos. Brasília: Ministério da Justiça, 1996.

RIBERIO, Carlos Antonio Costa. Cor e criminalidade: estudo e análise da justiça do Rio de Janeiro (1900 - 1930). Rio de Janeiro: EDUERJ, 1995.

SILVA, Jorge da. Direitos civis e relações raciais no Brasil. Rio de Janeiro: LUAM, 1994.

SILVA, Kátia Elenise Oliveira da. O papel do Direito Penal no enfrentamento da discriminação. Porto Alegre: Livraria do Advogado, 2001.

SCHWARCZ, Lilia Moritz. O espetáculo das raças: cientistas, instituições e questão racial no Brasil 1870 - 1930. São Paulo: Companhia das Letras, 1993.

STONE, I. O julgamento de Sócrates. São Paulo: Companhia das Letras, 1988.

TRINDADE, Augusto Cançado. O esgotamento de recursos internos no direito internacional. Brasília: UnB, 1997.

. Tratado de Direito Internacional dos Direitos Humanos. Porto Alegre:

Serio Antonio Fabris Editor, 1998.

WIEVIORKA, Michel. O Racismo, uma introdução. São Paulo: Perspectiva, 2007.

Recebido em 12-09-2011

Aprovado em 25-10-2011

Aprovado para publicação em 05-12-2011 